\title{
AC 2007-2685: FEMALE AMALGAMATION INTO INDUSTRIAL TECHNOLOGY AND FACTORS CAUSATIVE TO RECRUITMENT AND RETENTION
}

\section{Jessica Buck, Jackson State University}

Assistant Professor Jackson State University Department of Technology

Mississippi State University - PHD -Technology Ed

Mississippi State University -MST- Technology

Alcorn State University - BS - Industrial Tech 
Female Amalgamation into Industrial Technology and Factors

Causative to Their Recruitment and Retention

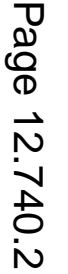




\section{Introduction}

Educational institutions are increasing their efforts to integrate females into nontraditional technical programs. Adjustments, such as curriculum and recruitment and retentions efforts, are being made to ensure that females feel welcome and a part of the program's standard regimen. Industrial Technology stands at the vanguard of successful paradigms that prepare females in such non-traditional areas as managerial and technical degree programs. Marshall $(2000)^{26}$ contended that the common goals of Industrial Technology programs are to increase enrollments and to offer a curriculum designed to prepare students for management and technical careers. O'Meara \& Carmichael (2004) $)^{34}$ added that emphasis should be placed on both recruitment and retention efforts the build enrollment numbers in technical programs. Areas of study, such as Industrial Technology, could provide possible managerial and technological career opportunities for females. The National Association of Industrial Technology (NAIT) defines Industrial Technology as a field of study designed to prepare technical and/or management oriented professionals for employment in business, industry, education, and government (as cited in McGowan, 1997) ${ }^{28}$. McGowan also added that Industrial Technology is primarily involved with the management, operation, and maintenance of complex technological systems while engineering and engineering technology are primarily involved with the design and installation of these systems.

Although females are increasing their representation in the non-traditional fields of study and are becoming more knowledgeable of technology's multi-facet components, there still remains significant under-representation of females in areas such as Industrial Technology. Nelson (2004) ${ }^{33}$ indicated that lack of female representation in technology may be due to a threefold purpose: "(1) women of the world lack knowledge of technology, (2) technology alienates and often exploits women, and (3) decisions about technology are made without women's voices" (p.2). This is reflected from Mayer's $(1995)^{27}$ assertion that females comprise only 30 percent of the industrial workforce. This globally illustrates moderate but consistent initiatives. The U. S. Department of Labor $(2003)^{38}$ reported that enhanced recruitment and retention strategies for females in technological and scientific areas would assist in increasing representation in the industrial workforce. Enhanced recruitment and retention efforts of females in Industrial Technology will be one step toward offsetting the shortage of representation in this field of study.

The representation of female faculty in Industrial Technology reflects a serious lack of gender diversity. The National Association of Industrial Technology (NAIT) (http://www.nait.org) ${ }^{32}$ revealed that there was only 11.2 percent female representation in an Industrial Technology faculty within the universities in the United States. Koerber (as cited in Nelson, 2004) ${ }^{33}$ contended that lack of female representation may result from the belief of technology being male-center and exclusive of female areas of proficiency. Under-representation has been present in the industrial workforce as well.

In the actual industrial setting, there once appeared to be a major division between male and female job positions and responsibilities. Appiah $(2002)^{5}$ indicated that 
traditional fields for males include: science, engineering, and other technical areas, while the traditional fields for females are education, history, and other social sciences. Bostic $(1999)^{9}$ suggested that this might be a result of females allowing traditional roles to determine their career choices.

Since Industrial Technology is a technical and management oriented profession, Orr (1983) ${ }^{33}$ asserted that some females viewed this as uncharted territory, and may be reluctant to manage large organizations or their male counterparts. However, Williams, Stead, and Posner (as cited in Orr, 1983) ${ }^{35}$ conducted studies revealing that women manage as well as their male counterparts. Although such findings may have been influential in females securing more jobs in management, Farrar \& Vogel $(2001)^{14}$ suggested that representation in technology remains at a slow increase, and efforts should be made to encourage female students to enter non-traditional fields.

\section{Research problem}

This study revealed that under-representation of females existed in Industrial Technology programs. At 5 of the four-year institutions in the state of Mississippi with Industrial Technology programs, female under-representation was evident. During the 2003-2004 academic school year, Alcorn State University's Department of Advanced Technologies enrolled 45 female students of 125 undergraduate students (K. Agyepong, personal communication, September 05, 2003) ${ }^{3}$. Jackson State's Technology Department had an enrollment of 80 female students out of 276 undergraduate students also during the 2003-2004 academic year (K. H. Jackson, personal communication, September 19, 2003) ${ }^{22}$. A. Stevens (personal communication, October 01, 2003) ${ }^{36}$ indicated that Mississippi State University's Industrial Technology program had an enrollment of 1 female student out of 63 undergraduate students. Mississippi Valley State's Industrial Technology department had an enrollment of 10 females out of 66 students (A. C. Favre, personal communication, October 20, 2003) ${ }^{15}$. In addition, C. Wentworth (personal communication, October 08, 2003) ${ }^{39}$ indicated that the University of Southern Mississippi's Industrial Engineer Technology program had an enrollment of 11 females (8 at the Hattiesburg-main campus, and 3 at the Gulf Coast campus) out of 75 students. Table 1 depicts the 2003-2004 academic school year's overall undergraduate enrollment in Mississippi Universities' Industrial Technology programs.

Table 1.Enrollment of Mississippi Industrial Technology undergraduate students

\begin{tabular}{|l|c|c|c|}
\hline \multicolumn{1}{|c|}{ Institution } & Male Students & Female Students & Total Enrollment \\
\hline Alcorn State & 80 & 45 & 125 \\
\hline Jackson State & 196 & 80 & 276 \\
\hline Mississippi State & 62 & 1 & 63 \\
\hline Mississippi Valley & 56 & 10 & 66 \\
\hline Uni. Of Southern MS & 64 & 11 & 75 \\
\hline
\end{tabular}


While literature indicates the moderate increase of females in science and technological fields, the question for this study becomes whether colleges and universities are making effective efforts to recruit and retain females in Industrial Technology.

Kasi and Dugger $(2000)^{25}$ stated that, "despite the gains by women, their participation has leveled off in many areas including Industrial Technology, and they have not achieved demographic parity or occupational equality with men (p. 4)." Kasi $(1999)^{24}$ further asserted that it is essential to conclude that gender generalization may have an impact on such under-representation by stereotypes, barriers, and perceptions of females in Industrial Technology. It is also significant to investigate any initiatives that may improve the overall environment for females enrolled in Industrial Technology programs.

The purpose of this study was to analyze efforts by the two NAIT (National Association of Industrial Technology) accredited Industrial Technology programs in the state of Mississippi - Alcorn State University and Jackson State University - toward recruitment and retention of females in this field of study. NAIT is the primary organization of Industrial Technology that provides direction and accrediting standards to programs and individuals. It is important to know whether gender generalizations exist within such programs. Also, it is essential to determine whether the learning environment promotes male/female equality. This study identified initiatives that Industrial Technology department chairs, program coordinators, and faculty could use to implement more meaningful recruitment practices for female students, thus, improving opportunities available to them.

\section{Methodology}

The study was conducted at Alcorn State University and Jackson State University. Alcorn State University is a land grant, historically black institution located in Lorman, (southwest) Mississippi, with an enrollment of 3,100 undergraduate students (http://www.alcorn.edu) ${ }^{1}$. Alcorn State University's Department of Industrial Technology currently has 45 female students out of 125 undergraduate students. The Department has 12 teaching faculty members (e.g. instructors, assistant professors, associate professors, and professors) (K. Agyepong, personal communication, September 05, 2003) ${ }^{3}$. However, as noted by Dr. B. W. McGowan (personal communication, September 16,2003$)^{29}$, only 1 of the 12 teaching faculty is a female who happens to be substituting for a male faculty member.

Jackson State University is an urban, historically black institution located in Jackson, (central) Mississippi. Jackson State University's current enrollment is 5,471 students (http://www.jsums.edu) ${ }^{23}$. Jackson State's Industrial Technology Department has an enrollment of 80 female students out of 276 undergraduate students (K. H. Jackson, personal communication, September 19, 2003) ${ }^{22}$. Dr. I. T. Mosley, (personal communication, September 06,2003$)^{30}$ affirmed that there are 9 teaching faculty members, none of whom are female. 
The population of this study consisted of a total of 146 students and faculty members. Forty-five female students and 12 faculty members where from Alcorn State University's Industrial Technology department and 80 female students, and 9 faculty members where from Jackson State University's Industrial Technology. However, only $29(64 \%)$ female students and $12(100 \%)$ faculty members from Alcorn State University, and $40(50 \%)$ female students and $9(100 \%)$ faculty members from Jackson State University participated in the study. The faculty from Alcorn State consisted of 11 males and 1 female. The faculty from Jackson State consisted of 9 males. Demographic information was obtained from the student survey.

\section{Instrumentation}

The design of the survey-questionnaire was guided by an instrument developed by Orr $(1983)^{35}$. Orr classified his survey-questionnaire procedure as nonexperimental research, because "it is not possible to manipulate variables or to assign subjects or conditions at random" (p. 54). According to Hung (1999) ${ }^{20}$, nonexperimental research does not render treatment to subjects, and the results describe how subjects naturally exist. Hung added that a common type of nonexperimental study is the survey in which subjects are questioned "to determine their attitudes, beliefs, and behaviors as they exist without experiment intervention" (p. 5). Therefore, this study implemented the nonexperimental research approach in order to determine attitudes of faculty and female students on female integration into Industrial Technology programs at Mississippi's fouryear NAIT accredited universities.

The faculty survey-questionnaire was designed in accordance with guidance from Devier $(1981)^{12}$. Each question on the survey-questionnaire was designed to answer the research questions 1 and 4 to meet the objective of this study: (1) What are the practices currently used to recruit and retain females into Industrial Technology the two NAIT accredited four-year institutions within the state of Mississippi: Alcorn State University and Jackson State University, and (4) What recommendations can be made by both faculty and students to integrate more female students into Industrial Technology programs. This required the participation of the Industrial Technology faculty members from both institutions; nonetheless, this was determined to be appropriate for data collection in this study.

This faculty survey-questionnaire consisted of 3 sections (e. g. Section $\underline{A}$.

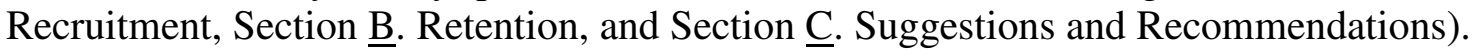
Section $\underline{A}$ addressed the use and perceived effectiveness of the various recruitment methods. The description of 20 recruitment methods was ranked on a 5-point Likert-type scale. The responses were ranked as $5=$ very effective, $4=$ effective, $3=$ ineffective, $2=$ very ineffective, and $1=$ not applicable. The last two questions in this section allowed the respondent to give an overall ranking of the recruitment initiative and their perceptions about other influential factors. Section $\underline{B}$ contained 5 questions in reference to retention. The items were focused on departmental and faculty efforts to promote inclusion and equality for both male and female students. Section $\underline{\mathrm{C}}$ gave the respondents the opportunity to make any suggestions and/or recommendations concerning efforts to 
improve and modify recruitment methods of female Industrial Technology students.

The student survey-questionnaire consisted of 6 sections (e.g. Section $\underline{A}$. Knowledge of Industrial Technology and Influences, Section $\underline{B}$. Career and Salary

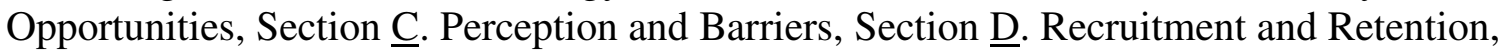
Section E. Demographics, and Section F. Suggestions and Recommendations). The questions were designed to answer research questions 2, 3, and 4: (2) What are the influences that help to integrate female students into Industrial Technology programs, (3) What are the barriers that female students perceive in studying Industrial Technology, an (4) What recommendations can be made by both faculty and students to integrate more female students into Industrial Technology programs. Section $\underline{A}$ inquired about first time knowledge of Industrial Technology programs, and prominent factors that influenced entrance into the program. Section $\underline{B}$ inquired about knowledge of career and salary opportunities available to females in Industrial Technology. Section $\underline{\mathrm{C}}$ sought to ascertain the female students' perception of their respective Industrial Technology departments. This section inquired about overall perception of Industrial Technology departments, greatest concerns about the programs, and apparent barriers female students have had to overcome. Section $\underline{D}$ allowed participants an opportunity to rank the initiatives that Industrial Technology departments have made to increase female enrollment on a 5-point Likert-type scale. The responses ranked as $5=$ very effective, 4 $=$ effective, $3=$ ineffective, $2=$ very ineffective, and $1=$ not applicable. Section $\underline{\mathrm{E}}$ contained demographic information (i.e. age, ethnicity, classification, and grade point average (G.P.A)). Section $\underline{F}$ provided the female students with the opportunity to make any suggestions and/or recommendations concerning efforts to improve and modify recruitment and retention practices.

\section{Discussion}

The examination of the data revealed the practices currently used to recruit and retain females into Industrial Technology at Alcorn State University and Jackson State University, the two NAIT accredited four-year institutions in the state of Mississippi as inquired from research question one. Collectively, both institutions indicated that effective recruitment practices included: distribute Industrial Technology literature to high schools and community colleges reflective of male and female participation, make visits to high schools and community colleges, and make presentations at freshman orientation. Effective retention of female Industrial Technology students included: promote learning environment conducive for both male and female students, encourage female Industrial Technology alumni to contact current female students, and keep female students well informed about Industrial Technology career opportunities.

Secondarily, the results reported revealed the effective recruitment and retention practices from the individual institution's Industrial Technology department. At Alcorn State University, the effective recruitment practices included: establish mailing list to potential students, send letters describing Industrial Technology opportunities, distribute Industrial Technology literature to high schools and community colleges reflective of male and female participation, make visits to high schools and community colleges, make 
presentations during freshman orientation, and influence from family, friends, and female faculty to pursue Industrial Technology Effective retention practices at Alcorn included: promote a learning environment conducive for both male and female students, encourage female Industrial Technology alumni to contact current female students, and keep female students well informed about Industrial Technology career opportunities. At Jackson State University, effective recruitment practices were to: distribute Industrial Technology literature to high schools and community colleges reflective of male and female participation, make presentation of Industrial Technology program opportunities to female students, make visits to high schools and community colleges, allow female students to arranging visits to tour the Industrial Technology Department, conduct recruitment conferences on campus, and make presentation during freshman orientation. Jackson State University's effective retention factors included: promote learning environment conducive for both male and female student, encourage female Industrial Technology alumni to contact current female students, and keep current female students well informed about Industrial Technology career opportunities.

During in 2003-2004 academic school year, 50\% of the Alcorn State's Industrial Technology faculty deemed their departmental recruitment practices effective, and 58\% deemed their retention practices for female students effective. Fifty-six percent of the Jackson State's Industrial Technology faculty indicated that their departmental recruitment practices were effective; and $78 \%$ indicated that their retention of female student practices were effective. For further study, current Industrial Technology enrollment of female students at Mississippi NAIT-accredited institutions will be needed. Efforts are currently being made to monitor the enrollment numbers of female students, how they were recruited, and how they are retained. Through communications with the Department Chair at Alcorn State University (Agyepong, 2006) ${ }^{4}$ and Jackson State University (Ejiwale, 2006) ${ }^{13}$, both departments of technology are using previous recruitment and retention strategies, however, they are continuing to identify methods to enhances those strategies. Progressive efforts are being made in both departments to enhance said strategies that will reflect the contemporary needs and desires of students such as strong articulations with community colleges, more recruitment at high schools, and more community outreach that will promote technology awareness. Nonetheless, future research endeavors will continue to assist in minimizing the lack of female participation. 
References

1. Alcorn State University. (n.d.). About Alcorn. Retrieved August 23, 2003, from http://www.alcorn.edu

2. Alcorn State University. (n.d.). About Alcorn. Retrieved October 31, 2006, from http://www.alcorn.edu

3. Agyepong, K. (personal communication, September 05, 2003).

4. Agyepong, K. (personal communication, November 09, 2006).

5. Appiah, E. N. (2002). Race and gender differences in educational attainment, field of study, and increments to earnings (evidence from University of Illinois tracer studies and nationwide earning data) (Doctoral dissertation, University of Illinois at UrbanaChampaign, 2002). Digital Dissertations, 63 (02), 157. (UMI No. 3044041).

6. Ayalon, H. (2003). Women and men go to university: mathematical background and gender difference in choices of field in higher education. Sex Roles, 48 (5/6), 277-290.

7. Ayers-Hillard, K. (1999). Identifying factors of non-traditional female students attrition in an urban environment (Doctoral dissertation, University of Houston, 1999). Digital Dissertations, 60 (04), 109. (UMI No. 9929264)

8. Bak, H. J. (2001). Education and public attitudes toward science: implication for "deficit model" of education and support for science and technology. Social Science Quarterly, 82 (4), 779-796.

9. Bostic, M. L. (1999). Unsuitable job for a woman? Women at work, status and issues. Journal of Industrial Technology, 15 (1), 2-6. Retrieved August 08, 2003, from http://www.nait.org

10. Burger, C. J. (2002). Helping girls take a byte out of technology. Principal, 81 (3), 4243. http://www.npg.si.edu/educate/bethune.htm

11. Busch, A. H. (2002). Developing quality school-to-work programs. Business Education Forum, 56 (3), 56-57.

12. Devier, D. H. (1981). Industrial arts teacher education, student recruitment practices and their effectiveness in the state of Ohio. (Doctoral dissertation, Ohio State University, 1981). Digital Dissertation, 42 (05), 159.

13. Ejiwale, J. A. . (personal communication, September 19, 2006).

14. Farrar, M. S. \& Vogel, F. A. (2001). Women's contributions to the workforce: are new measures need? Paper presented at the meeting of the International Statistical Institute, Seoul Korea.

15. Favre, A. C. (personal communication, October 20, 2003). 
16. Francis, B. (1998). Power plays: primary school children constructions of gender, power, and adult work. (ERIC Document Reproduction Service No. ED437464)

17. Garelik, G. (2000). Report urges to recruit, retain more women and minorities. Bioscience, 50 (11), 962.

18. Hansen, L. S. (2000). The future of industrial technology education (Doctoral dissertation, University of Wyoming, 2000). Digital Dissertation, 61 (11), 164. (UMI No. 9993735)

19 Henwood, F. (1998). Engineering difference: discourse on gender, sexuality and work in a college of technology. Gender and Education, 10, (01), 35-50.

20. Heskett, J. (2001). Past, present, and future in design for industry. Design Issues, 17 (1), 27.

21. Hung, T. Y. (1999). Industrial technology teachers' perceptions of the Arkansas adopted exploring industrial technology education junior high school program (Doctoral dissertation, University of Arkansas, 1999). Digital Dissertation, 61 (03), 88. (UMI No. 9967761)

22. Jackson, K. H. (personal communication, September 19, 2003).

23. Jackson State University (n.d.) About Jackson State. Retrieved August 23, 2003, from http://www.jsums.edu

24. Kasi, B. (1999). The gender dimension in industrial technology faculty (Doctoral dissertation, Iowa State University, 1999). Digital Dissertations 60(08), 153. (UMI No. 9940213)

25. Kasi, B. \& Dugger, J. C. (2000). Gender equity in industrial technology: the challenge and recommendations. Journal of Industrial Technology, 16 (4), 2-9. Retrieved August 08, 2003, from http://www.nait.org

26. Marshall, J. A. (2000). Focus on industry for success. Journal of Industrial Technology, 16 (3), 25. Retrieved August 08, 2003, from http://www.nait.org

27. Mayer, E. (1995). Women, industry and technology. UNIDO: Document \# 3797. Retrieved September 14, 2003, from http://undio.org/en/doc/view/3797

28. McGowan, B. W. (1997). An investigation of student and faculty learning style congruency and academic achievement in an undergraduate industrial technology program (Doctoral dissertation, Mississippi State University, 1997). Digital Dissertations 58(12), 122. (UMI No. 9818694)

29. McGowan, B. W. (personal communication, September 16, 2003).

30. Mosley, I. T. (personal communication, September 06, 2003).

31. Motamedi, V. (2000). Preparation in the use of technology among teacher education majors at Mississippi State University (Doctoral dissertation, Mississippi State University, 2000). Digital Dissertations 61(04), 167. (UMI No. 9970336)

32. National Association of Industrial Technology (NAIT). (n.d.). Retrieved June, 2006, from http://www.nait.org

33. Nelson, S. (2004). Women's voices are missing from technology. Journal of Industrial 
Technology, 20 (2), 2-8. Retrieved September 26, 2006, from http://www.nait.org

34. O'Meara, R, \& Carmichael, M. (2004). recruitment strategies for industrial programs. Journal of Technology Studies, 30 (4), 13-16. Retrieved January 1, 2007, from

http://scholar.lib.vt.edu/ejournals/JOTS/v30/v30n4/pdf

35. Orr, J.P. (1983). Factors influencing participation of females in the industrial technology program at Southern Illinois University-Carbondale (Doctoral dissertation, Southern Illinois University, 1983). Digital Dissertations 47(07), 151.

36. Stevens, A. (personal communication, October 01, 2003).

37. United Automobile, Aerospace and Agricultural Implement Workers of America. (n.d.). Women in the workforce. Retrieved September 02, 2003, from http://www.uaw.org/publications/jobs_pat/00/1000/jpe04.html

38. U. S. Department of Labor. (2003, December 1). Occupational Employment Statistics. Retrieved December 11, 2003, from http://www.dol.gov

39. Wentworth, C. (personal communication, October 08, 2003). 